UDC 504.054

DOI https://doi.org/10.32851/2226-0099.2021.121.36

\title{
INVESTIGATION OF THE POSSIBILITY OF PROBIOTIC USE FOR REMEDIATION OF CONTAMINATED SOIL OF SOLID DOMESTIC WASTE LANDFILLS
}

\author{
Pysarenko P.V. - Doctor of Agricultural Sciences, Professor, \\ Head of the Department of Ecology, Sustainable Use of Nature \\ and Environmental Protection, \\ Poltava State Agrarian University \\ Samoilik M.S. - Doctor of Economic Sciences, Professor, \\ Professor at the Department of Ecology, Sustainable Use of Nature \\ and Environmental Protection, \\ Poltava State Agrarian University \\ Taranenko A.O. - Candidate of Agricultural Sciences, Senior Lecturer, \\ Senior Lecturer at the Department of Ecology, Sustainable Use of Nature \\ and Environmental Protection, \\ Poltava State Agrarian University \\ Tsova Yu.A. - Candidate of Agricultural Sciences, \\ Senior Lecturer at the Department of Ecology, Sustainable Use of Nature \\ and Environmental Protection, \\ Poltava State Agrarian University \\ Sereda M.S. - PhD student at the Department of Ecology, \\ Sustainable Use of Nature and Environmental Protection, \\ Poltava State Agrarian University
}

The imperfection of modern methods and measures to minimize the impact of solid domestic waste dumps on the environment necessitated the solution of a scientific and practical problem: studying the peculiarities of toxic effects of the leachate from solid domestic waste dumps and developing methods to restore the contaminated lands around solid domestic waste dumps in order to return them to the economic turnover. The conducted research is a comprehensive analysis of the impact of solid domestic waste dumps on the germination, growth and root system of planted out Avéna sativa seeds. The prospects of using the probiotic preparations Sviteco-Agrobiotic-01 (1: 100 dilution) for the remediation of the contaminated lands of domestic waste dumps are studied. The results showed that seed germination of Avéna sativa in the contaminated soil was $17 \%$ lower than in the clean soil (control). On day 7 , the average root length of Avéna sativa in the variants with contaminated soil was found to be $44 \%$ shorter and the average length of the aerial part of the plant was $22 \%$ shorter compared to the control. The root system weight of Avéna sativa plants in the soil from the waste dump was $55 \%$ lower compared to the control, and the weight of the aerial part of the plant was $42 \%$ lower. It was found that when the probiotic Sviteco - Agrobiotic-01 (1: 100 dilution) was added to the contaminated soil, the germination of Avéna sativa seeds was 5.2\% higher compared to the variant without adding the probiotic. The use of the probiotic improved the biometric indicators of Avena sativa: the weight of the root system and the aerial part of the plant increased by $16.5 \%$ and $14 \%$ compared to the contaminated soil without cleanup. The results confirmed that after using Sviteco - Agrobiotic-01 (1: 100 dilution) the soil had medium toxicity in terms of root weight and deficient (weak) toxicity in terms of root length of Avéna sativa. The use of Sviteco - Agrobiotic-01 in combination with $\mathrm{Ca}(\mathrm{OH}) 2$ at $\mathrm{pH}=10$ makes it possible to reduce significantly the toxic effects on biota and increase the efficiency of technogenically contaminated soil cleanup. Thus, the use of the probiotic improves the efficiency of the system of technogenically contaminated soil cleanup as a result of municipal solid waste disposal. The conducted research is the basis for the development of the technology of biological treatment of leachate at solid domestic waste dumps and landfills, which will contribute to solving priority problems.

Key words: leachate, domestic waste dump, probiotic, contaminated soil, Avéna sativa, phytotoxic effects. 
Писаренко П. В., Самойлик М. С., Тараненко А. О., Цьова Ю. А., Середа М. С. Дослідження можливості використання пробіотиків для рекультивацї забрудненого грунту полігонів твердих побутових відходів

Недосконалість сучасних методів та заходів із мінімізації впливу звалищ твердих побутових відходів на довкілля зумовили необхідність розв'язання такого науково-практичного завдання: вивчення особливостей токсичного впливу фільтрату від звалищ побутових відходів і розроблення методів відновлення забруднених земель у районі розташування звалищ твердих побутових відходів із метою повернення їх у господарський обіг. Проведене дослідження є комплексним аналізом впливу звалища твердих побутових відходів на схожість, picm i кореневу систему висадженого насіння Avéna satíva. Досліджено перспективи використання пробіотичних препаратів Sviteco - Agrobiotic-01» (розчинення 1:100) задля відновлення забруднених земель звалищ побутових відходів. Результати дослідження показали, щзо схожість насіння Avéna satíva y забрудненому трунті була на 17\% меншою порівняно з чистим трунтом (контролем). На сьому добу встановлено, що середня довжина коренів Avéna satíva y варіантах із забрудненим грунтом була меншою на 44\%, а середня довжина наземної частини рослини - на 22\% порівняно із контролем. Маса кореневої системи рослин Avéna satíva у трунті зі звалиша відходів була меншою на 55\% порівняно із контролем, а маса надземної частини рослини - на 42\%. Встановлено, щз за внесення пробіотику Sviteco - Agrobiotic-01 (розчинення 1:100) у забруднений трунт схожість насіння Avéna satíva була на 5,2\% вищою порівняно з варіантом без додавання пробіотику. Використання пробіотику покращило біометричні показники Avéna sativa: маса кореневої системи та наземної частини рослин збільшилися відповідно на 16,5 \% і 14\% порівняно із забрудненим трунтом без очищення. Результати дослідження підтвердили, щзо після використання Sviteco - Agrobiotic-01» (розчинення 1:100) трунт характеризувався середньою токсичністю за показником маси коренів $і$ відсутністю або слабкою токсичністю - за показником довжини коренів Avéna sativa. Використання пробіотику Sviteco - Agrobiotic-01 у комплексі з Ca $(\mathrm{OH})_{2}$ за $\mathrm{pH}=10$ дозволяе значно знизити токсичний вплив на біоту $і$ підвищити ефективність очищення техногенно забруднених трунтів. Отже, використання пробіотику дозволить підвищити ефективність системи очищення техногенно забрудненого трунту внаслідок розміщення звалищ твердих побутових відходів. Проведені дослідження є основою для розроблення технології біологічного очищення фільтрату на звалищах і полігонах твердих побутових відходів, щцо сприятиме вирішенню першочергових екологічних проблем.

Ключові слова: фільтрат, звалище побутових відходів, пробіотик, забруднений трунт, Avéna sativa, фітотоксичний вплив.

Problem statement. Anthropogenic pollution of the environment results in the degradation of ecological systems, global climatic and geochemical changes as well as regional and local ecological crises and disasters. Lithosphere is mostly damaged due to human activity. Surface solid waste storage pits, in particular sewage waters of domestic solid waste (MSW) landfill, cause damage to flora and fauna, health of the population and affect dynamic balance of the biosphere as a result of non-compliance with rules of their storage and burial. Particular danger to the environment exists due to heavy metal pollution, from filtrates removed from landfills and precipitation which contact with landfill substrates. The accumulation of toxic substances leads to gradual change of the chemical composition of soils, violation 
of integrity of geochemical environment and living organisms. Any pollution of a lithosphere with solid wastes can entail the pollution of surface, underground water and the atmosphere. Despite this fact, the most widespread method of waste handling in many countries of the world, including Ukraine, is their burial. Valuable agricultural resources are used as waste sites [1].

Analysis of current research. Works of researchers are devoted to the improvement of solid waste handling: Amos R. [2], Yunjiang Y. [3], Wierzbicki A. [4], Gerding J. [5], Vagin V. [6], Burkinsky B. [7], Singh C. [8] and others. But the issue of reducing the area of contaminated lands, which formation is caused by waste disposal places, as well as their restoration and return to economic turnover are insufficiently studied and remain relevant for scientific community. Methods of biological land restoration, in particular probiotic, are also becoming especially relevant $[9,10]$. In the presence of a wide range of methods of reclamation of technogenic contaminated lands by domestic waste dump, the use of probiotics for the reduction of pollution is insufficiently studied. Widespread use of probiotic is hampered by insufficient study of this area: there is no scientific and scientific-practical base, comparative studies of different probiotics, methods of calculating the required doses, profits to obtain a given cleansing effect and more.

The purpose of the research is to study the toxic impact of leachate from domestic waste landfill on the stability of Avéna sativa and to develop recommendations on the improvement of leachate treatment around landfill.

Main material of research. The article evaluates the phytotoxicity of contaminated soil before and after cleaning with probiotics. Method of seedlings based on the reaction of the test culture when applying to the soil different pollutants. It allows you to detect the toxic or stimulating effects of those or other substances [11]. Cleaning of contaminated soils is carried out by biological methods, use probiotic Sviteko-Agrobiotic-01 (1:100 dilution).

At the first stage Avéna sativa was seeded in separate containers with different samples of soil (100 pieces each). Four pilot sites with quadruple repetition are identified (Table 1). The soil was collected via standard techniques from the territory of the MSW landfill, located $750 \mathrm{~m}$ southeast from Makukhovka village (Poltava district, Poltava region, Ukraine). The area of a landfill is 17.4 hectares. Filling is $105 \%$. The place of waste disposal is disordered, its opportunities to accept and neutralize waste are fully utilized. The filtrate is accumulated from the north side of the MSW landfill. The potential volume of the filtrate is $51975.2 \mathrm{~m}^{3} /$ year [12]. Determination of phytotoxicity of a filtrate was made by Gritsaenko G. method [13]. The experiment was carried out during 14 days, then the following was defined: quantity of germinated seeds; length of ground parts of plants; length of roots (after drying) and their weight (weighing in Petri dish). Chemical analysis of the filtrate and soil was performed in a certified laboratory of agroecological monitoring of Poltava State Agrarian Academy according to generally accepted methods (ДСТУ 17.4.4.02:2019; ДСТУ 4770.9:2007; ДСТУ 4770.3:2007; ДСТУ 4770.5:2007; ДСТУ 4770.1:2007; ДСТУ 7965:2015; ДСТУ 4770.6:2007; ДСТУ 4770.2:2007; ДСТУ 7965:2015; MBB 31-497058-009-2002).

At the second stage we studied the phytotoxic influence of a dump filtrate after its cleaning with $\mathrm{Ca}(\mathrm{OH})_{2}$ (lime hydrate) and Sviteco - Agrobiotic-01 (1:100 dilution) for Avéna sativa growth and root system. Avéna sativa was seeded 100 pieces in separate containers with soil from the MSW landfill (eight pilot sites with quadruple repetition, Table 1). 
Table 1

Modification of the experiment

\begin{tabular}{|c|c|c|c|}
\hline $\begin{array}{c}\text { stage of } \\
\text { work }\end{array}$ & $\begin{array}{c}\text { site } \\
\text { number }\end{array}$ & soil (clean/ contaminated) & water (with probiotic / without probiotic) \\
\hline \multirow{4}{*}{1} & $\mathrm{a}$ & $\begin{array}{l}\text { control site of clean soil } \\
\text { (standard) }\end{array}$ & watering with clear water (distilled) \\
\hline & $\mathrm{b}$ & site of clean soil & $\begin{array}{l}\text { watering with distilled water with Sviteco- } \\
\text { Agrobiotic-01 (1:100 dilution) }\end{array}$ \\
\hline & $\mathrm{c}$ & site of soil from MSW dump & watering with distilled water without prebiotic \\
\hline & d & site of soil from MSW dump & $\begin{array}{l}\text { watering with distilled water with Sviteco- } \\
\text { Agrobiotic-01 (1:100 dilution) }\end{array}$ \\
\hline \multirow{8}{*}{2} & $\mathrm{a}$ & \multirow{8}{*}{ site of clean soil } & $\begin{array}{l}\text { watering with drinking water (local well) and } \\
\text { addition of } \mathrm{Ca}(\mathrm{OH}) \text {, at } \mathrm{pH} 9.0\end{array}$ \\
\hline & b & & $\begin{array}{l}\text { watering with a filtrate from the MSW dump } \\
\text { and addition of } \mathrm{Ca}(\mathrm{OH}) \text {, at } \mathrm{pH} 8.4\end{array}$ \\
\hline & $\mathrm{c}$ & & $\begin{array}{l}\text { watering with a filtrate from the MSW dump } \\
\text { and addition of } \mathrm{Ca}(\mathrm{OH})_{2} \text { at } \mathrm{pH} 9.3\end{array}$ \\
\hline & d & & $\begin{array}{l}\text { watering with a filtrate from the MSW dump } \\
\text { and addition of } \mathrm{Ca}(\mathrm{OH}) \text {, at } \mathrm{pH} 10.0\end{array}$ \\
\hline & $\mathrm{e}$ & & $\begin{array}{l}\text { watering with drinking water (local well) and } \\
\text { addition of } \mathrm{Ca}(\mathrm{OH})_{2} \text { at } \mathrm{pH} 9.45 \text { and Sviteco- } \\
\text { Agrobiotic-01 (1:100 dilution) }\end{array}$ \\
\hline & $\mathrm{f}$ & & $\begin{array}{l}\text { watering with a filtrate from the MSW dump } \\
\text { and addition of } \mathrm{Ca}(\mathrm{OH})_{2} \text { at } \mathrm{pH} 8.35 \text { and Sviteco- } \\
\text { Agrobiotic- } 01(1: 100 \text { dilution })\end{array}$ \\
\hline & g & & $\begin{array}{l}\text { site with watering with a filtrate from the MSW } \\
\text { dump and addition of } \mathrm{Ca}(\mathrm{OH})_{2} \text { at } \mathrm{pH} 9.31 \text { and } \\
\text { Sviteco- Agrobiotic- } 01(1: 100 \text { dilution })\end{array}$ \\
\hline & $\mathrm{h}$ & & $\begin{array}{l}\text { Site with watering with a filtrate from the MSW } \\
\text { dump and addition of } \mathrm{Ca}(\mathrm{OH}) 2 \text { at } \mathrm{pH} 10.0 \text { and } \\
\text { Sviteco- Agrobiotic-01 (1:100 dilution) }\end{array}$ \\
\hline
\end{tabular}

The experiments were conducted within a month then the following was defined: quantity of germinated seeds; length of ground parts of plants; length of roots (after drying) and their weight (weighing in Petri dish). Repeatability of experiments - four times, single trial establishment. To check the reliability of the difference, the Student's coefficient was defined after testing for normality of distribution between statistical characteristics of two alternative data sets [14].

The phytotoxic influence of soil on Avéna sativa growth and root system was defined as follows [15]:

$$
P I=\left(\frac{M_{0}-M_{k}}{M_{0}}\right) \cdot 100 \%
$$

where $M_{o}$ - weight or growth indicators of plants with a control sample of soil;

$M_{k}$ - weight or growth indicators of plants in the studied soil.

The results of quantitative chemical analysis of the filtrate showed the excess of maximum permissible concentrations (MPC) in general indexes (color, smell, total alkalinity, total hardness), petroleum products, hydrogen sulfide and heavy metals. The total hardness of filtrate was 1.13 MPC. The content of petroleum products in filtrate 
exceed the MPC by 10 times. The content of such heavy metals as $\mathrm{Pb}, \mathrm{Co}, \mathrm{Mn}, \mathrm{Cu}, \mathrm{Zn}$ significantly exceeds the established norms. (Table 2).

Table 2

Results of quantitative chemical analysis of the filtrate from solid domestic waste landfill (Makukhovka village, Poltava region)

\begin{tabular}{|c|c|c|c|c|c|c|c|}
\hline Index & Units & $\begin{array}{c}\text { Method of } \\
\text { measurement }\end{array}$ & Sample 1 & $\begin{array}{c}\text { Error } \\
\pm \Delta\end{array}$ & Sample 2 & $\begin{array}{c}\text { Error } \\
\pm \Delta\end{array}$ & $\begin{array}{c}\text { MPC } \\
\text { * no } \\
\text { more }\end{array}$ \\
\hline \multicolumn{8}{|c|}{ General indexes } \\
\hline Color & deg & \multirow{4}{*}{ ГОСТ 3351-74 } & 25 & - & 45 & - & 20 \\
\hline $\begin{array}{l}\text { Turbidity (by } \\
\text { kaolin) }\end{array}$ & $\mathrm{mg} / \mathrm{dm}^{3}$ & & 1,3 & 0,47 & 3,8 & 0,47 & 3 \\
\hline Smell & grade & & 3 & - & 2 & - & 2 \\
\hline $\mathrm{pH}$ & - & & 8,28 & 0,2 & 8,12 & 0,2 & $6-9$ \\
\hline Total alkalinity & $\mathrm{mg} / \mathrm{dm}^{3}$ & ГОСТ 31957-2012 & 497 & 50 & 101,2 & 50 & 350 \\
\hline Total hardness & mg- equiv/ $\mathrm{dm}^{3}$ & ГОСТ 31954-2012 & 6,8 & 0,3 & 6,4 & 0,3 & 6,0 \\
\hline \multicolumn{8}{|c|}{ Biogenic elements } \\
\hline $\mathrm{N}-\mathrm{NO}_{3}$ & $\mathrm{mg} / \mathrm{dm}^{3}$ & ГОСТ 33045-2014 & 10,1 & 1,04 & 3,8 & 1,04 & 45,0 \\
\hline $\mathrm{N}_{\mathrm{NO}}$ & $\mathrm{mg} / \mathrm{dm}^{3}$ & ГОСТ 18826-73 & 0,34 & 0,03 & 0,026 & 0,03 & 3,0 \\
\hline Mineralization & $\mathrm{mg} / \mathrm{dm}^{3}$ & ГОСТ 18164-72 & 640 & 58 & 142 & 52 & 1000 \\
\hline P content & $\mathrm{mg} / \mathrm{dm}^{3}$ & ГОСТ 18309-2014 & 2,1 & 0,04 & 0,9 & 0,02 & 3,5 \\
\hline $\mathrm{SO}_{4}^{2-}$ & $\mathrm{mg} / \mathrm{dm}^{3}$ & ГОСТ 4389-72 & 168 & 82 & 341 & 87 & 500 \\
\hline $\mathrm{Cl}^{-}$ & $\mathrm{mg} / \mathrm{dm}^{3}$ & ГОСТ 18190-72 & 284 & 2,0 & 296 & 2,0 & 350,0 \\
\hline $\begin{array}{c}\text { Chemical } \\
\text { oxygen demand }\end{array}$ & $\mathrm{mgO}_{2} / \mathrm{dm}^{3}$ & ГОСТ 4245-72 & 2,3 & 0,3 & 1,8 & 0,32 & 5,0 \\
\hline $\begin{array}{c}\text { Petroleum } \\
\text { products }\end{array}$ & $\mathrm{mg} / \mathrm{dm}^{3}$ & ГОСТ 31859-2012 & 0,1 & - & 0,08 & - & $\leq 0,01$ \\
\hline $\mathrm{H}_{2} \mathrm{~S}$ & $\mathrm{mg} / \mathrm{dm}^{3}$ & МУК 4.1.1013-01 & 1,04 & 0,23 & 1,02 & 0,23 & 1,0 \\
\hline \multicolumn{8}{|c|}{ Content of heavy metals } \\
\hline $\mathrm{Pb}$ & $\mathrm{mg} / \mathrm{dm}^{3}$ & ГОСТ 18293-72 & 0,58 & 0,04 & 0,32 & 0,04 & 0,3 \\
\hline $\mathrm{Cr}(+6)$ & $\mathrm{mg} / \mathrm{dm}^{3}$ & ГОСТ 31956-2012 & 0,06 & 0,007 & 0,07 & 0,007 & 0,05 \\
\hline $\mathrm{Fe}$ & $\mathrm{mg} / \mathrm{dm}^{3}$ & ГОСТ 4011-72 & 2,38 & 0,012 & 5,34 & 0,012 & 0,3 \\
\hline Co & $\mathrm{mg} / \mathrm{dm}^{3}$ & MУ 31-14/06 & 0,15 & 0,08 & 0,08 & 0,03 & 0,1 \\
\hline $\mathrm{Mn}$ & $\mathrm{mg} / \mathrm{dm}^{3}$ & ГОСТ 4974-2014 & 0,12 & 0,002 & 0,11 & 0,002 & 0,1 \\
\hline $\mathrm{Ni}$ & $\mathrm{mg} / \mathrm{dm}^{3}$ & MУ $31-14 / 06$ & 0,03 & 0,007 & 0,02 & 0,007 & 0,1 \\
\hline $\mathrm{Cu}$ & $\mathrm{mg} / \mathrm{dm}^{3}$ & ГОСТ 4388-72 & 1,54 & 0,010 & 1,12 & 0,010 & 1,0 \\
\hline $\mathrm{Zn}$ & $\mathrm{mg} / \mathrm{dm}^{3}$ & ГОСТ 18293-72 & 6,7 & 0,73 & 9,4 & 0,73 & 5,0 \\
\hline
\end{tabular}

The results of quantitative chemical analysis of the soil from solid domestic waste landfill showed content of heavy metals and petroleum products, which significantly exceeds the established norms of the Order of the Ministry of Health of 14.07.2020 № 1595 "On approval of the Hygienic regulations of the permissible content of chemicals in the soil". Content of petroleum products was $1.15 \mathrm{MPC}$, content of $\mathrm{Pb}, \mathrm{Cu}, \mathrm{Co}$ significantly exceeds the established norms (Table 3). 
Table 3

\section{Results of quantitative chemical analysis of the soil from solid domestic waste} landfill (Makukhovka village, Poltava region)

\begin{tabular}{|c|c|c|c|c|c|}
\hline Indexes & Units & Value & MPC * & Cd** & $\begin{array}{c}\text { Method of measurement and error, } \\
\boldsymbol{P}=\mathbf{0 , 9 5})\end{array}$ \\
\hline $\mathrm{pH}$ & & 7,50 & $6,0-9,0$ & 7,90 & $\begin{array}{c}\text { ДСТУ } 4770.9: 2007 . \\
\delta= \pm(3-20) \%\end{array}$ \\
\hline $\begin{array}{c}\text { Organic } \\
\text { matter }\end{array}$ & $\%$ & 3,7 & $\geq 2$ & 5,5 & $\begin{array}{c}\text { ГОСТ } 23740-79 \\
\delta= \pm(15-10) \%\end{array}$ \\
\hline $\mathrm{P}_{\text {general }}$ & $\%$ & 0,75 & - & 0,45 & $\begin{array}{c}\text { ДСТУ } 4290: 2004 \\
\delta= \pm(5-20) \%\end{array}$ \\
\hline $\begin{array}{c}\text { Amonium } \\
\mathrm{N}\end{array}$ & $\mathrm{mg} / \mathrm{kg}$ & 114,11 & - & 141,56 & $\begin{array}{c}\text { ДСТУ ISО/TS14256-1:2005 } \\
\delta= \pm(9-20) \%\end{array}$ \\
\hline $\begin{array}{c}\text { Petroleum } \\
\text { products }\end{array}$ & $\mathrm{mg} / \mathrm{kg}$ & 1150,47 & 1000 & 110,51 & $\begin{array}{c}\text { МВВ 31-497058-009-2002 } \\
\delta= \pm(5-20) \%\end{array}$ \\
\hline $\mathrm{Pb}$ & $\mathrm{mg} / \mathrm{kg}$ & 44,21 & 32,0 & 1,66 & $\begin{array}{c}\text { ДСТУ } 4770.9: 2007 \\
\delta= \pm 20 \%\end{array}$ \\
\hline $\mathrm{Mn}$ & $\mathrm{mg} / \mathrm{kg}$ & 974,65 & 1500 & 189,65 & $\begin{array}{c}\text { ДСТУ } 4770.1: 2007 \\
\delta= \pm 10 \%\end{array}$ \\
\hline $\mathrm{Cr}(+6)$ & $\mathrm{mg} / \mathrm{kg}$ & 0,06 & 0,05 & 0,02 & $\begin{array}{c}\text { ДСТУ 7965:2015 } \\
\delta= \pm 20 \%\end{array}$ \\
\hline $\mathrm{Fe}$ & $\mathrm{mg} / \mathrm{kg}$ & 710,65 & - & 410,56 & $\begin{array}{c}\text { ДСТУ } 7913: 2015 \\
\delta= \pm 14 \%\end{array}$ \\
\hline $\mathrm{Cd}$ & $\mathrm{mg} / \mathrm{kg}$ & 1,4 & 1,5 & $\leq 0,05$ & $\begin{array}{c}\text { ДСТУ } 4770.3: 2007 \\
\delta=15 \%\end{array}$ \\
\hline $\mathrm{Cu}$ & $\mathrm{mg} / \mathrm{kg}$ & 3,95 & 3,0 & 2,15 & $\begin{array}{c}\text { ДСТУ } 4770.6: 2007 \\
\delta= \pm 15 \%\end{array}$ \\
\hline $\mathrm{Co}$ & $\mathrm{mg} / \mathrm{kg}$ & 22,80 & 5,0 & 3,10 & $\begin{array}{c}\text { ДСТУ } 4770.5: 2007 \\
\delta= \pm 22 \%\end{array}$ \\
\hline $\mathrm{Ni}$ & $\mathrm{mg} / \mathrm{kg}$ & 3,90 & 4,0 & 2,80 & $\begin{array}{c}\text { ДСТУ } 7965: 2015 \\
\delta= \pm 15 \%\end{array}$ \\
\hline $\mathrm{Zn}$ & $\mathrm{mg} / \mathrm{kg}$ & 15,70 & 23,0 & 13,45 & $\begin{array}{c}\text { ДСТУ } 4770.2: 2007 \\
\delta= \pm 20 \%\end{array}$ \\
\hline
\end{tabular}

* _ * according to the Order of the Ministry of Health from 14.07.2020 № 1595 About the statement of Hygienic regulations of admissible maintenance of chemicals in soil

** background value.

So, resuarch results showed considerable contamination of filtrat from solid domestic waste landfill and as result considerable contamination of soil in plases around solid domestic waste landfill. Therefore there is a need of phytotoxic assessment of contaminated lands around the landfill at a distance of $500 \mathrm{~m}$ and $1000 \mathrm{~m}$, which are used and / or can be used in agriculture.

The study represents a complex analysis of the influence of the MSW landfill on growth and root system of probiotic Sviteko-Agrobiotic-01 (1:100 dilution) at the first stage, and addition of prebiotic and $\mathrm{Ca}(\mathrm{OH})_{2}$ at various $\mathrm{pH}$ values at the second stage.

The results of the first stage allowed defining the following. On the seventh day of experiment germinated seeds in site 1a (control) was $95 \%$, in site $1 \mathrm{~b}$ (clean soil and watering with prebiotics) $-97 \%$, in site $1 \mathrm{c}$ (contaminated soil and watering without prebiotic) $-69 \%$, in site $1 \mathrm{~d}$ (contaminated soil and watering with prebiotics) $-85 \%$. 


\section{Influence of contaminated soil from waste disposal sites on biometric indicators of Avéna satíva}

\begin{tabular}{|l|c|c|c|c|c|}
\hline \multicolumn{1}{|c|}{ Variants } & $\begin{array}{c}\text { Germination } \\
\text { seeds, \% } \\
\text { (average } \\
\text { indicator) }\end{array}$ & $\begin{array}{c}\text { Length of } \\
\text { ground part } \\
\text { of plant, cm } \\
\text { (average } \\
\text { indicator) }\end{array}$ & $\begin{array}{c}\text { Average } \\
\text { length of } \\
\text { roots, cm. }\end{array}$ & $\begin{array}{c}\text { Weight of } \\
\text { ground part } \\
\text { of plant, g. }\end{array}$ & $\begin{array}{c}\text { Weight } \\
\text { of root } \\
\text { system, g. }\end{array}$ \\
\hline $\begin{array}{l}\text { 1a (clear soil + distilled } \\
\text { water) }\end{array}$ & 94.9 & 26.76 & 11.32 & 4.27 & 2.34 \\
\hline 1b (clear soil + probiotic) & 98.0 & 29.26 & 13.30 & 4.52 & 2.61 \\
\hline $\begin{array}{l}\text { 1c ( contaminated soil + } \\
\text { distilled water) }\end{array}$ & 69.2 & 20.73 & 6.31 & 2.03 & 1.33 \\
\hline $\begin{array}{l}\text { 1 d (contaminated soil + } \\
\text { probiotic) }\end{array}$ & 85.4 & 23.46 & 10.53 & 2.87 & 1.69 \\
\hline
\end{tabular}

The received results allowed concluding that the germinated seeds in the soil collected around the MSW landfill are 17\% lower in comparison with the control, ground parts of plants are $22 \%$ less, the average length of roots is $44 \%$ less. The weight of ground part and weight of a root system of plants in the soil from the dump is $55 \%$ and $42 \%$ less respectively. Probiotic use in control (reference) and in variant with polluted soil gave the following results:

- germinated seeds in the clear soil sample were by $1.5 \%$ better with probiotic, in contaminated soil from the landfill - by $5.2 \%$ respectively;

- the length of ground part in clear soil with addition of probiotic was by $9.4 \%$ more, in contaminated soil from the landfill - by $11.6 \%$ respectively;

- the average length of roots in clear soil with probiotic was by $11.7 \%$ more, in contaminated soil from the landfill - by $40.2 \%$ respectively;

- the weight of ground part and weight of a root system of plants in clear soil with probiotic was by $5.6 \%$ and $11.5 \%$ higher, in contaminated soil from the landfill - by $14 \%$ and $16.5 \%$ respectively.

The phytotoxicity of soil by length and weight of land and root parts of a plant was calculated (Figure 1).

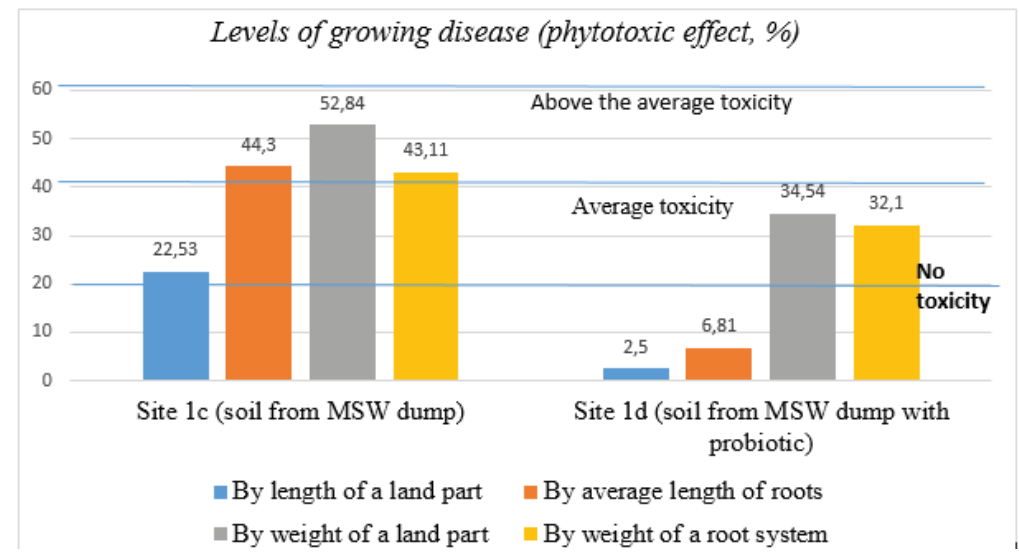

Figure 1. Assessment of phytotoxic effect of the soil from the MSW landfill on the example of Avéna sativa cultivation 
The second stage included the study of the phytotoxic influence of a filtrate from the MSW landfill after its cleaning with $\mathrm{Ca}(\mathrm{OH})_{2}$ and probiotic Sviteko-Agrobiotic-01 (1:100 dilution) on germination, growth and the root system of Avéna satíva (Table 5).

Table 5

Assessment of contaminated filtrate from the MSW dump on the example of Avéna satíva cultivation at various methods of cleaning

\begin{tabular}{|c|c|c|c|c|c|c|c|}
\hline Variants & $\mathbf{p H}$ & $\begin{array}{c}\text { Germinated } \\
\text { seeds, \% } \\
\text { (average } \\
\text { indicator) }\end{array}$ & $\begin{array}{c}\text { Length of } \\
\text { ground } \\
\text { part, cm } \\
\text { (average } \\
\text { indicator) }\end{array}$ & $\begin{array}{c}\text { Length of } \\
\text { roots, cm } \\
\text { (average } \\
\text { indicator) }\end{array}$ & $\begin{array}{c}\text { Weight } \\
\text { of root } \\
\text { system, g } \\
\text { (average } \\
\text { indicator) }\end{array}$ & $\begin{array}{c}\text { Weight of } \\
\text { ground } \\
\text { part, g } \\
\text { (average } \\
\text { indicator) }\end{array}$ & $\begin{array}{c}\text { Average } \\
\text { root weight } \\
\text { of one } \\
\text { seed, g }\end{array}$ \\
\hline $2 \mathrm{a}$ & 9.0 & 94.6 & 26.7 & 11.3 & 2.34 & 4.27 & 0.025 \\
\hline $2 \mathrm{~b}$ & 8.4 & 81.3 & 12.0 & 6.5 & 1.45 & 2.36 & 0.0178 \\
\hline $2 \mathrm{c}$ & 9.3 & 90.0 & 18.0 & 8.1 & 1.73 & 2.87 & 0.0192 \\
\hline $2 \mathrm{~d}$ & 10.0 & 84.0 & 16.0 & 7.0 & 1.65 & 2.73 & 0.0196 \\
\hline $2 \mathrm{e}$ & 9.45 & 96.0 & 27.2 & 11.5 & 2.45 & 4.85 & 0.027 \\
\hline $2 \mathrm{f}$ & 8.35 & 92.0 & 18.4 & 8.4 & 1.79 & 2.92 & 0.0195 \\
\hline $2 \mathrm{~g}$ & 9.31 & 84.0 & 13.0 & 6.8 & 1.53 & 2.6 & 0.018 \\
\hline $2 \mathrm{~h}$ & 10.0 & 93.0 & 22.0 & 10.9 & 2.34 & 4.6 & 0.025 \\
\hline
\end{tabular}

Note. 2a- clean water $+\mathrm{Ca}(\mathrm{OH})_{2}$ at $\mathrm{pH} 9.0$;

$2 \mathrm{~b}$ - filtrate $+\mathrm{Ca}(\mathrm{OH})_{2}, \mathrm{pH} 8,4$;

$2 \mathrm{c}$ - filtrate $+\mathrm{Ca}(\mathrm{OH})_{2}, \mathrm{pH} 9,3$;

$2 \mathrm{~d}$ - filtrate $+\mathrm{Ca}(\mathrm{OH})_{2}, \mathrm{pH} 10,0$;

$2 \mathrm{e}-$ clean water $+\mathrm{Ca}(\mathrm{OH})_{2}, \mathrm{pH} 9.45+$ probiotic.

$2 \mathrm{f}$ - filtrate $+\mathrm{Ca}(\mathrm{OH})_{2}, \mathrm{pH} 8,35+$ probiotic;

$2 \mathrm{~g}$ - filtrate $+\mathrm{Ca}(\mathrm{OH})_{2}, \mathrm{pH} 9,31+$ probiotic;

$2 \mathrm{~h}$ - filtrate $+\mathrm{Ca}(\mathrm{OH})_{2}, \mathrm{pH} 10,0+$ probiotic.

It is proved that the addition of $\mathrm{Ca}(\mathrm{OH})_{2}$ and probiotic Sviteko-Agrobiotic-01 (1:100 dilution) at $\mathrm{pH} 10$ gives the maximum filtrate cleaning. In variants with probiotic germinated seeds were $84-93 \%$. In variants with only $\mathrm{Ca}(\mathrm{OH})_{2}$ application at different $\mathrm{pH}$ values germinated seeds were $81-90.0 \%$. Length of ground part were large in variants with probiotic application $(13-22 \mathrm{~cm})$, in variants with only $\mathrm{Ca}(\mathrm{OH})_{2}$ application were $12-18 \mathrm{~cm}$. Similar results were obtained through the assessment of the weight of root system, weight of underground part, average root weight of one seed (Fig. 2).

Application probiotic allows improving the soil quality and reducing its phytotoxicity. In particular, if the toxic influence on a root system of contaminated soil was characterized as above the average, after probiotic application toxic influence was weak (absent) according to the levels of growing disease (Table 6).

It is established that the use of $\mathrm{Ca}(\mathrm{OH})_{2}$ and probiotic Sviteko-Agrobiotic-01 (1:100 dilution) at $\mathrm{pH}=10$ allows improving the quality of anthropogenic polluted soil, reducing toxic impact on biota and increasing the efficiency of filtrate in MSW landfill (Fig. 3). 


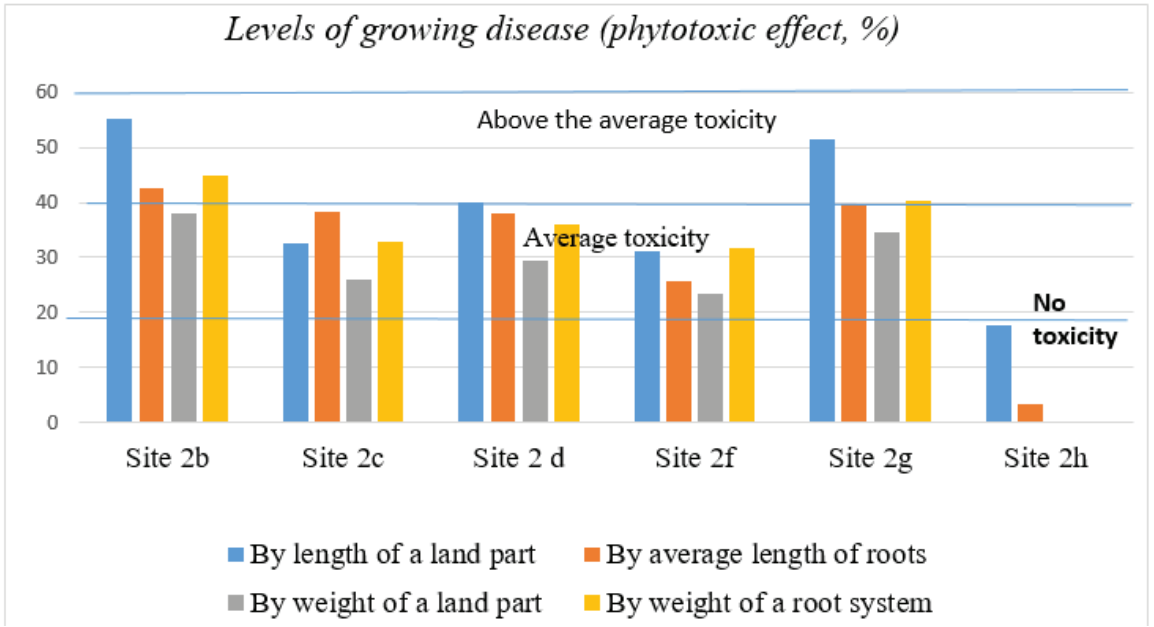

Figure 2. The results of the assessment of the phytoxic effect based of Avéna sativa cultivation with different cleaning methods

Table 6

Assessment of phytotoxic effect of a filtrate from the MSW landfill on the example of Avéna satíva cultivation

\begin{tabular}{|c|c|c|c|c|}
\hline \multirow[b]{2}{*}{ Variants } & \multicolumn{4}{|c|}{ Levels of growing disease (phytotoxic effect, \%) } \\
\hline & $\begin{array}{c}\text { By length of } \\
\text { ground part of } \\
\text { plant }\end{array}$ & $\begin{array}{c}\text { By average } \\
\text { length of roots }\end{array}$ & $\begin{array}{c}\text { By weight of } \\
\text { ground part of } \\
\text { plant }\end{array}$ & $\begin{array}{l}\text { By weight of a } \\
\text { root system }\end{array}$ \\
\hline $\begin{array}{l}\text { Site with watering with } \\
\text { a filtrate }+\mathrm{Ca}(\mathrm{OH}) 2 \text { at } \\
\text { pH } 8.4\end{array}$ & $\begin{array}{c}55.06 \\
\text { Above the } \\
\text { average toxicity }\end{array}$ & $\begin{array}{c}42.48 \\
\text { Above the } \\
\text { average toxicity }\end{array}$ & $\begin{array}{c}38.03 \\
\text { Average toxicity }\end{array}$ & $\begin{array}{c}44.73 \\
\text { Above the } \\
\text { average toxicity }\end{array}$ \\
\hline $\begin{array}{l}\text { Site with watering with } \\
\text { a filtrate }+\mathrm{Ca}(\mathrm{OH}) 2 \text {, } \\
\text { pH } 9.3\end{array}$ & $\begin{array}{c}32.58 \\
\text { Average toxicity }\end{array}$ & $\begin{array}{c}28.32 \\
\text { Average toxicity }\end{array}$ & $\begin{array}{l}26.07 \\
\text { Average toxicity }\end{array}$ & $\begin{array}{l}32.79 \\
\text { Average toxicity }\end{array}$ \\
\hline $\begin{array}{l}\text { Site with watering with } \\
\text { a filtrate }+\mathrm{Ca}(\mathrm{OH}) 2 \text {, } \\
\mathrm{pH} 10.0\end{array}$ & $\begin{array}{c}\text { Above the } \\
\text { average toxicity }\end{array}$ & $\begin{array}{c}38.05 \\
\text { Average toxicity }\end{array}$ & $\begin{array}{c}29.49 \\
\text { Average toxicity }\end{array}$ & $\begin{array}{c}36.07 \\
\text { Average }\end{array}$ \\
\hline $\begin{array}{l}\text { Site with watering with } \\
\text { a filtrate }+\mathrm{Ca}(\mathrm{OH}) 2+ \\
\text { probiotic, } \mathrm{pH} 8.35\end{array}$ & $\begin{array}{c}31.09 \\
\text { Average toxicity }\end{array}$ & $\begin{array}{c}25.66 \\
\text { Average toxicity }\end{array}$ & $\begin{array}{c}23.50 \\
\text { Average toxicity }\end{array}$ & $\begin{array}{c}31.62 \\
\text { Average toxicity }\end{array}$ \\
\hline $\begin{array}{l}\text { Site with watering with } \\
\text { a filtrate and addition of } \\
\mathrm{Ca}(\mathrm{OH}) 2+\text { probiotic, } \\
\text { pH } 9.31\end{array}$ & $\begin{array}{c}51.31 \\
\text { Above the } \\
\text { average toxicity }\end{array}$ & $\begin{array}{c}39.82 \\
\text { Average toxicity }\end{array}$ & $\begin{array}{c}34.62 \\
\text { Average toxicity }\end{array}$ & $\begin{array}{c}40.15 \\
\text { Above the } \\
\text { average toxicity }\end{array}$ \\
\hline $\begin{array}{l}\text { Site with watering with } \\
\text { a filtrate and addition of } \\
\mathrm{Ca}(\mathrm{OH}) 2+\text { probiotic, } \\
\mathrm{pH} 10\end{array}$ & $\begin{array}{c}17.60 \\
\text { No (weak) } \\
\text { toxicity }\end{array}$ & $\begin{array}{c}3.54 \\
\text { No (weak) } \\
\text { toxicity }\end{array}$ & $\begin{array}{c}\mathbf{0 . 0 0} \\
\text { No toxicity }\end{array}$ & $\begin{array}{c}\mathbf{0 . 2 3} \\
\text { No toxicity }\end{array}$ \\
\hline
\end{tabular}




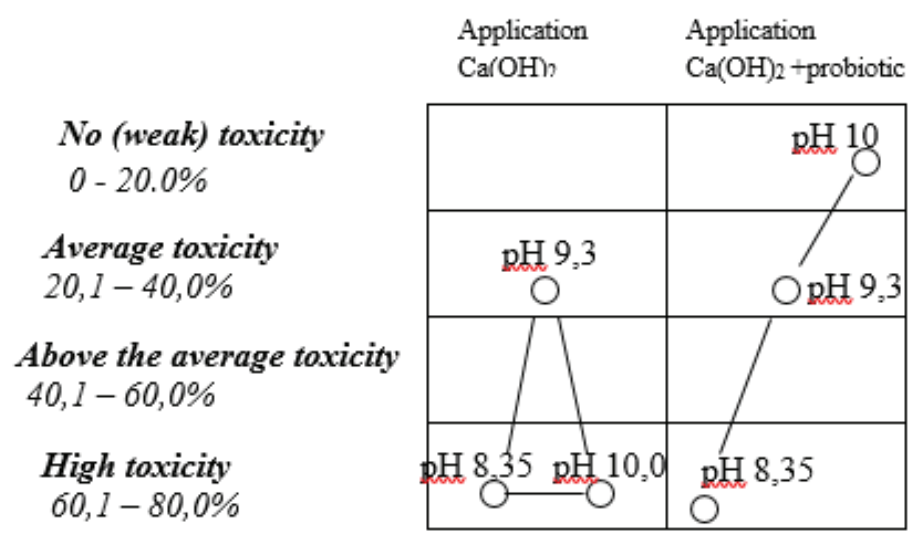

Figure 3. The results of the evaluation of the phytotoxic effect on Avéna sativa depending on the cleaning methods and different $\mathrm{pH}$

Conclusion. The experiments allowed estimating the phytotoxic effect of a filtrate from the MSW landfill on the example of Avéna sativa cultivation and recommending methods of leachate treatment at solid domestic waste landfill:

1. Phytotoxic effect of the soil from the MSW landfill. Germinated seeds were on $17 \%$ lower, length of ground part was on $22 \%$ lower, the average length of roots was on $44 \%$ lower in comparison with control (clean soil). The weight of ground part and weight of a root system of plants in the soil from the landfill was on $55 \%$ and $42 \%$ less respectively. Influence of pollutants was characterized as the above average toxicity.

2. Application of probiotic Sviteko-Agrobiotic-01 (1:100 dilution) for cleaning contaminated soil. Germinated seeds were better on 5.2\% in comparison with the polluted soil without the probiotic, the length of ground part of plants was large on $11.6 \%$, the average length of roots - on $40.2 \%$ respectively; the green weight of ground part of plants and the weight of a root system of plants were on $14 \%$ and $16.5 \%$ higher in comparison with the polluted soil without the probiotic application. Thus, the use of prebiotics allows improving the quality of soil and reducing its phytotoxicity. In particular, if the influence on a root system of the contaminated soil is characterized as toxic above the average, after probiotic application - as the average toxicity by root weight and absent (weak) toxicity by root length. Application probiotic Sviteko-Agrobiotic-01 (1:100 dilution) and $\mathrm{Ca}(\mathrm{OH})_{2}$ at $\mathrm{pH}=10$ the maximum cleaning effect was reached, the phytotoxic effect is estimated as weak toxicity (by the length of ground part according to the average length of roots) and as no toxicity (by the weight of a ground part, weight of a root system). The phytotoxic effect of the filtrate without cleaning above the average toxicity.

Thus, the use of $\mathrm{Ca}(\mathrm{OH})_{2}$ and probiotic Sviteko-Agrobiotic-01 (1:100 dilution) at $\mathrm{pH}=10$ allows improving the quality of contaminated soil, reducing toxic impact on biota and increasing the efficiency of leachate treatment in MSW landfill.

\section{REFERENCES:}

1. Chachina S.B., Chachina S.B., Voronkova N. A., Baklanova O.N. Biological remediation of the engine lubricant oil-contaminated soil with three kinds of earthworms, Eisenia fetida, Eisenia andrei, Dendrobena veneta, and a mixture of microorganisms. Procedia Engineering. 2015. Vol. 113. P. 113-123. 
2. Amos R. T., Blowes D.W., Bailey B. L., Sego D. C., Smith L., Ritchie A. I.M. Waste-rock hydrogeology and geochemistry. Applied Geochemistry. 2015. Vol. 57. P. 140-156. doi:10.1016/j.apgeochem.2014.06.020

3. Yunjiang Y., Ziling Y., Peng S., Bigui L. Effects of ambient air pollution from municipal solid waste landfill on children's non-specific immunity and respiratory health. Environmental Pollution. 2018. Vol. 236. P. 382-390. doi:10.1016/j.envpol.2017.12.094.

4. Wierzbicki A. Model-based decision support methodology with environmental applications. Kluwer Academic Publishers. IIASA Institute for Applied Systems Analysis Dordrecht. 2013. No 2. P. 67-71.

5. Gerding J., Kirshy M., Moran J. W., Bialek R., Lamers V., Sarisky, J. A. Performance management initiative for local health department vector control programs. Environmental Health. 2016. Vol. 83.

6. Vagin V. S. Integrated management of MSW life cycle in the region: conceptual and terminological-methodological bases of the concept: monograph Rostov-ob-Don: Publishing house of NCRCHS, 2004. P. 111.

7. Буркинский Б.В., Степанов В. Н., Гаричков С.К. Економико-экологические основы регионального природопользования и развития. Одесса : ИПРЕИИ НАН, 2005.

8. Singh C., Kumar A., Roy S. Estimating potential methane emission from municipal solid waste and a site suitability analysis of existing landfills in Delhi, India. Technologie. 2017. No 5 (4). P. 62-68. doi:10.3390/technologies5040062.

9. Adebola A.A., Iheoma M. A., Igba O. T. Impact of bioremediation formulation from Nigeria local resource materials on moisture contents for soils contaminated with petroleum products. International Journal of Engineering Research and Development. 2012. No 2 (4). P. 40-45.

10. Anjana S., Poonam K., Meenal B. R. Biodegradation of diesel hydrocarbon in soil by bioaugmentation of Pseudomonas aeruginosa: a laboratory scale study. International Journal of Environmental Bioremediation \& Biodegradation. 2014. No 2 (4). P. 202-212.

11. Мовчан Я. Ю., Канаевский В. А., Семьячевский В. Д. Фитоиндикация в дистанционных исследованиях. Киев, 1993.

12. Голік Ю.С. Довкілля Полтавщини: монографія. Полтава : Копіцентр, 2014.

13. Грицаєнко Н. М. Методи біологічних та агрохімічних досліджень рослин та грунтів. Київ : Нічлава, 2003. 320 с.

14. Филенко О.Ф. Методы биотестирования качества водной среды и почвы. Москва : Изд-во Моск. ун-та, 1989. 124 с. 